\title{
Impact of Government Agricultural Expenditure on Agricultural Productivity in Nigeria
}

\author{
Sebastian 0 Uremadu ${ }^{1 *}$, Florence 0 Ariwa $^{2}$ and Charity E Duru Uremadu ${ }^{3}$ \\ ${ }^{1,2}$ Department of Banking and Finance, MOUAU, Nigeria \\ ${ }^{2}$ Department of Banking and Finance, Michael Okpara University of Agriculture, Nigeria \\ ${ }^{3}$ Department of Educational Management, MOUAU, Nigeria
}

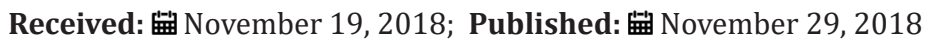

*Corresponding author: Sebastian O Uremadu, Department of Banking and Finance, MOUAU, Nigeria

Abstract

The study examined effect of government agricultural expenditure on agricultural output in Nigeria using time series data from 1981 to 2014. Having analyzed data using unit root test, co-integration test and vector error correction model, results of unit root test showed that all the variables were integrated at the first order difference. On the other hand, the Johansen co-integration tests revealed that a long-run relationship existed between agricultural output and government agricultural expenditure. Going through the vector error correction model results indicated that agricultural output adjusted rapidly to changes in total government agricultural expenditure, real exchange rate, banking system credit to agriculture, average annual rainfall and population growth rate. With respect to individual variables, average annual rainfall and domestic population growth rate were significant at 1 percent levels in affecting agricultural output in Nigeria. While domestic population growth rate lead agricultural output in Nigeria, average annual rainfall followed and then government expenditure, and finally, real exchange rate in their descending order of magnitude. As such, it was recommended that government should not only adequately fund agriculture via maintaining a healthy population but to also encourage a mechanized agricultural system by use of modern technology and inputs to boost yields in local rice production and other farm produce so as to reduce the rate of rice importation in the country. Moreover, government should ensure that meteorological agencies which forecast annual rainfalls are well funded and catered for and that their recommendations be implemented towards achieving high farm yields annually and food self-sufficiency thereby minimizing agricultural losses due to vagaries of weather in our agricultural climate.

Keywords: Agricultural Output; Government Expenditure; Gross Capital Formation

\section{Introduction}

Economic history shows that agricultural revolution is basic precondition for economic growth, especially in developing countries [1]. Agriculture is the life blood of industrialization in the world. According to Akintunde [2], every industrialized country passed through the agrarian era. The maxim that agriculture is the hub of the Nigerian economy underscores the importance placed on agriculture as the engine for growth. Prior to the discovery of oil, the Nigerian economy was predominantly agriculture with abundance of arable land and water resources to foster agricultural development [3]. As it were, the agricultural sector contributed immensely to the Nigerian economy in provision of food for the increasing population, supply of raw materials to industries, major source of employment and generation of foreign exchange earnings $[4,5]$. As such, literature abound that stagnation in agricultural production accounts for the economic failure facing Nigeria, while the acceleration in agricultural productivity is the key explanation to industrialization in the developed countries $[6,7]$. Consequently, the development of agriculture in every country in the world (both developed and underdeveloped) requires government assistance [8]. In recent years, agricultural output in other regions have been doubling, while Nigeria has experienced a significant decline in agricultural output [9-11]. Consequently, following the stunt growth in agricultural output in developing countries, low agricultural investments have been seen as a major contributory factor to this development [12]. As such, government fiscal responsibility has always been seen as a fundamental stability, often viewed as prerequisite to achieving sustainable output growth [13]. Hence, the potential contribution of agriculture to economic development in Nigeria have been marred by poor funding, coupled with misguided government policies [1,14]. Agricultural sector in the 1960s contributed about 64 percent of the total gross domestic product (GDP) of Nigeria, but gradually declined to $48 \%$ in the 1970 s during 
the oil boom [15]. Nigeria, has diverse agro-ecological conditions that can support a variety of farming models, which can create its own agricultural models. However, successive administrations over the years neglected the agricultural sector in favour of the oil industry $[16,17]$.

Public expenditure, which serves as the bed rock of financing for the sector has consistently fallen short of the public expectation $[6,18]$. For instance, a collaborative study carried out by the International Food Policy and Research Institute (IFPRI) and the World Bank in 2008 revealed that Nigeria's public expenditure on agriculture is less than 2percent of total federal annual budget expenditure. This is significantly below the expected amount or international standard compared to other developing countries like Kenya (6 percent), Brazil (18 percent) and 10 percent goal set by African Leaders Forum, under the Comprehensive Africa Agricultural Development Programme (CAADP) in the current decade. In spite of poor investment, agriculture has on the average contributed 32 percent of the country's GDP from 1996 to 2000 and 42 percent between 2001 and 2009 (CBN, 2010). According to the Central Bank of Nigeria (CBN), in 2011 agriculture accounted for 40 percent of the nation's GDP, yet it received only one per cent of the total commercial bank loans [16]. The objective of this paper is to analyze impact of Federal Government agricultural expenditure on agricultural productivity in Nigeria. By the time it is completed we shall be in a position to ascertain how much has been achieved in this regard.

\section{Literature Review}

\section{Government Involvement in Agriculture in Nigeria}

Government spending plays an important role in agricultural development $[18,19]$. This is based on the economic ideology that agricultural development is a process that involves adoption by farmers of new production practices and the acquisition of new input materials [2]. Unfortunately, the rural capital market cannot supply the needed funds to finance such innovations. Consequently, agricultural development in Nigeria as in similar developing nations has been stunted. The problem of agricultural finance then becomes that of finding adequate fund for agricultural development, identifying the right farmers who could benefit from such fund, extending such fund to the right section are the Nigerian farm credit corporation and the new programmes. Having realized the declining role agriculture sector has had to economic development, the government over the years have put in place certain policy measures and programmes with a view to increasing the contribution of agriculture to economic development in Nigeria. However, a peep into the Federal Government capital expenditure on agriculture portraits a gloomy future for the sector's development in the country. As indicated in Table 1, from 1981 to 2014, the Federal Government capital expenditure on agriculture were low. Despite these huge sums of money allocated to the sector over these years (Table 1), there was little or insignificant improvement in agricultural production because successive governments only used the policies/programmes to embezzle public funds to the total neglect of food production by refusing to pay farmers the true value of their crops and at the same time selling fertilizer and seeds to them at high prices [2].

Table 1: Federal Government Capital Expenditure on Agriculture (1981-2014)

\begin{tabular}{|c|c|c|c|}
\hline Year & $\begin{array}{c}\text { Government } \\
\text { Agricultural } \\
\text { Expenditure } \\
\text { BILLION }\end{array}$ & $\begin{array}{c}\text { Total } \\
\text { Government } \\
\text { Expenditure } \\
\text { BILLION }\end{array}$ & $\begin{array}{c}\text { Agricultural } \\
\text { Output } \\
\text { BILLION }\end{array}$ \\
\hline 1981 & 0.81 & 11.41 & 19.53 \\
\hline 1982 & 1.07 & 11.92 & 22.56 \\
\hline 1983 & 1.21 & 9.64 & 26.44 \\
\hline 1984 & 0.29 & 9.93 & 33.78 \\
\hline 1985 & 1.01 & 13.04 & 38.24 \\
\hline 1986 & 0.93 & 16.22 & 39.93 \\
\hline 1987 & 0.39 & 22.02 & 57.58 \\
\hline 1988 & 0.65 & 27.75 & 86.58 \\
\hline 1989 & 1.06 & 41.03 & 120.06 \\
\hline 1990 & 1.96 & 60.27 & 122.23 \\
\hline 1991 & 0.67 & 66.58 & 144.70 \\
\hline 1992 & 0.92 & 92.80 & 217.42 \\
\hline 1993 & 2.83 & 191.23 & 350.05 \\
\hline 1994 & 3.72 & 160.89 & 528.95 \\
\hline 1995 & 6.93 & 248.77 & 940.30 \\
\hline 1996 & 5.57 & 337.22 & 1275.75 \\
\hline 1997 & 7.92 & 428.22 & 1445.15 \\
\hline 1998 & 11.84 & 487.11 & 1600.58 \\
\hline 1999 & 10.04 & 947.69 & 1704.82 \\
\hline 2000 & 10.59 & 701.06 & 1801.48 \\
\hline 2001 & 64.94 & $1,018.03$ & 2410.05 \\
\hline 2002 & 44.80 & $1,018.16$ & 2847.11 \\
\hline 2003 & 16.05 & $1,225.97$ & 3231.44 \\
\hline 2004 & 49.93 & $1,426.20$ & 3903.76 \\
\hline 2005 & 76.66 & $1,822.10$ & 4752.98 \\
\hline 2006 & 107.46 & $1,938.00$ & 5940.24 \\
\hline 2007 & 38.83 & $2,450.90$ & 6757.87 \\
\hline 2008 & 39.47 & $3,240.82$ & 7981.40 \\
\hline 2009 & 504.29 & $3,452.99$ & 9186.31 \\
\hline 2010 & 412.20 & $4,194.58$ & 10310.66 \\
\hline 2011 & 386.40 & $4,712.06$ & 11593.43 \\
\hline 2012 & 321.04 & $4,605.39$ & 13413.84 \\
\hline 2013 & 505.77 & $5,185.32$ & 14709.10 \\
\hline 2014 & 181.83 & $4,578.06$ & 14642.76 \\
\hline
\end{tabular}


The food pricing and exchange rate policies of government have over the years been relatively low to the world market prices and in most cases, what is paid to the farmers has been half the world price. The continuous depreciation of the Naira (local currency) and the ineffective system of subsidies for inputs have also had their toll on agricultural finance. For, instance, the subsidies which were aimed at helping the poor, ended up reducing the income of the farmers who were much poorer than many of the urban consumers who actually benefited from the subsidies. The consequence of this is that these policies have reduced farmers incentives for production while consumption of urban dwellers have continued to increase thus making government rely on imported food dumped by industrialized countries, which in turn makes farmers to abandon their farms and migrate to the cities [20]. Rapid advances in agricultural production in Nigeria have also been a constraint to agricultural finance. For example, technology has vastly increased the productivity of farm labour and greatly decreased the number of farms labourers needed. This scenario has resulted in a steady decline in the cost of production and a decline in crop prices. The fall in crop price with increasing opportunities in urban areas have combined to create a strong incentive for rural-urban migration. Besides, Nigeria government has taken advantage in the reduction of food prices to increase their food import to the neglect of the agricultural sector, thus increasing the government food import bills which further impede finance to the agricultural sector [21].

Another constraint to agricultural finance in Nigeria is the delay in the disbursements of loans to farmers. According to Aku et al. [22], farmers in Nigeria are usually confronted with delays in the disbursements of loans approved by government. These loans sometimes came after the planting season and with the actual disbursement falling far short of loan needed and approved. Even when these loans were disbursed early, it did not get to the poor farmers but rather to the rich farmers who would divert such loans to other activities that have no effect or bearing on agricultural production in most cases. Some of these rich farmers at times have failed to pay back such loans because they could not be penalized due to has been termed "high political cost." Farmers are also exposed to natural hazards such as infestation of crops by pest and diseases, inadequate rainfall, soil erosion and retardation in the conduct of extension activities and the adoption of new improved farming techniques following the financial crisis which most Agricultural Development Projects (ADP) faced as a result of the phasing out of the World Bank loan facilities following the failure of the government to account for already disbursed loans.

\section{The Role of Agricultural Financing and its Implication on Economic Growth, Food Security and Poverty Reduction}

There has been serious argument on agricultural financing as a declining sector in the course of development in many developing countries; it is still a leading economic sector, the main exporter, and the major employer, especially for the poor and women even among Nigerians. Improved financial markets accelerate agricultural and rural growth. Financial services assist households in maintaining food security and smoothening consumption, thereby safeguarding or enhancing labour productivity which have been the most important production factor of the poor [23]. Studies also have not identified any effects of financial liberalization on the price and availability of informal credit to agriculture [24]. Nigeria Agricultural Cooperative and Rural Development Bank (NACRDB) cost of loan to agricultural sector have not been stable since 1990 to 2006, but from 2007 till date, the cost of loan to agricultural sector has been stable at 8 percent rate. At present; Nigerian banks lend less that 3 percent of their commercial loans to agricultural sector. In 2005, agricultural lending was only 2.44 percent of commercial banks total loan portfolio, it fell to 1.96 percent in 2006, 3.11 percent in 2007 and 1.37 percent in 2008.Yet, most of the poor still live in rural areas because of not having access to agricultural credit. There is serious need for agricultural credit to farmers to increase or improve on the present dispensation.

Any student of an introductory course in micro-economics, business finance or development economics or even entrepreneurship studies learns that access to savings, credit and insurance services could have beneficial effects on households and their enterprises and by extension on economic growth, and that microfinance in particular, might also contribute to more equitable growth of the nation's economy. Access to credit especially agricultural sector, however, has an economic benefit only if and when that access generates a broadly defined net economic surplus after having deducted the private and social costs of loan provision (including the opportunity costs of scarce public funds in alternative poverty reduction policies) of government. While the evidence on the impact of credit on household welfare, agricultural technology adoption, and on agricultural sector growth is mixed, many practical constraints (i.e. in terms of time and money) and methodological difficulties in estimating the impact of a policy or project with a reasonable probability of error exists. Simple common sense tells us that savers who continue to deposit money for different motives, borrowers who continue to repay their loans and clients paying regular premiums for health and life insurance over long periods actually derive an economic benefit [25].

\section{Empirical Literature Works Cited}

In spite of the important role which the agricultural sector plays in the development of a nation, successive Nigerian governments at the Federal, State and Local Government levels have not been able to adequately address these specific constraints to agricultural productivity in an attempt to increase agricultural production in Nigeria. For example, the current Minister of Agriculture Chief Audu Ogbe was reported to have said that "nevertheless, the agricultural sector's contributions to the economic growth and development 
are yet to be fully exploited since Nigerians are still very vulnerable to hunger and poverty" [26]. The poor who live in the rural and urban centre usually constitute a large percentage of the population in the country and they are the dominant producers of food and other essential materials; yet the formal financial institutions have not adequately provided financial services to them as a result of their stringent conditions for making funds available to farmers as well as the lack of access to available funds. These are among the constraints envisaged in Agricultural production in the country.

In addition, the process of acquiring a loan entails a lot of paperwork and many bureaucratic procedures which lead to extra transaction costs. The formal financial institutions are not motivated to lend to farmers due to vulnerability of agricultural practice to risk and inability in yields as a result of the vagaries of weather. These institutions show a preference for large scale transaction over small scale associated credit transaction and nonagricultural over agricultural loans [3]. For instance, Mehrteab (2005), stated that in Africa, only 5 percent of the farmers had access to formal credit; hence this situation calls for a shift in attention by the Government to the recognition and development of the informal financial institutions that are predominantly found in the rural areas where agriculture thrives. Besides, there are little or no existing studies known to the author on the evaluation of the impact of government agricultural expenditure on agricultural output in Nigeria. This explains the need for the present study.

Ewubare and Eyitope [14], examined the effects of government spending on the agricultural sector in Nigeria using quasiexperimental research design. The time series data adopted in the study were generated from the Central Bank of Nigeria (CBN) Annual Statistical Bulletin 2013 and National Bureau of Statistics Bulletin 2013. The ordinary least square of multiple regression, the Johansen co-integration techniques, and the error correction model were used for the tests and analysis. The results showed that the coefficient of determination was 0.9468 (94.68\%) and the coefficient of the ECM exhibited a negative sign and statistically significant. Durbin-Watson statistics value was 1.954 and the F-statistics of 33.84 was significant at $5 \%$ level. In specific terms, the lag two and three forms of the explanatory variables on government agricultural expenditure were positive and statistically significant. Based on the findings, the study recommended increased funding of these agricultural sector in Nigeria. Alabi [1], also investigated the impact of foreign agricultural aid on agricultural GDP and productivity in Sub-Saharan Africa (SSA) using the right multiple regression analysis and data. The results revealed that the average sectoral aid allocation to agriculture in SSA was 7 percent during the period studied, growing from 18 million USD in 2002 to about 47 million USD in 2010. The econometric analysis results suggested that foreign agricultural aid had a positive and significant impact on both agricultural GDP and agricultural productivity at 10 percent level of significance, and that disaster and conflict also have a positive and significant impact on aid receipt at 5 percent significance. Saungweme and Matandare [27] tested the effects of central government's expenditure towards the agricultural sector and the subsequent effect of this on economic activities in Zimbabwe. The results indicated that increased agriculture expenditure before 2000 boosted production in the sector and strengthened forward and backward economic linkages. However, the land reform programme of 2000 and subsequent reduction in sound government support to the sector contributed immensely to the economic crises in Zimbabwe afterwards. Their work recommended effective government support to the agricultural sector through credible productive policies and financial and/or non-financial resources. Odi N [28] examined agricultural financing in Nigeria and its implications on the growth of the Nigerian economy using ordinary least square method (OLS) and quantitative research design. The study observed that there was a significant relationship between agricultural financing and the growth of the Nigerian economy and that the level of loan repayment rate over the years has indeed negatively impacted significantly on the growth of the Nigerian economy. The result has an important implication in terms of policies that will enhance economic growth through agricultural financing. We therefore recommend that, having seen that there is long-run relationship between Nigeria Agricultural Cooperative and Rural Development Bank (NACRDB) agricultural financing and economic growth in Nigeria, there is need to increase the level and size of NACRDB agricultural loans through the reduction of interest rate to allow for more economic development in the country. Akintunde WA [2] analyzed the effectiveness of government annual budgetary allocation to agriculture and the role of monetary policy instruments in the growth of agricultural GDP, covering the period of 1980-2012. The results of the analysis showed that Agricultural Credit Guarantee Scheme Fund, previous year GDP and Consumer Price Index contributed positively to the growth of agricultural GDP, other variables of interest like the interest rate, exchange rate, and government expenditure on agriculture contributed negatively to agricultural GDP growth. The study therefore recommended that government should increase her spending to the agricultural sector, monitor the fund allocated, and provide the necessary infrastructural facilities like good road network, electricity health and water for the rural populace. Yeun [7] used panel data from 1995 to 2011 to estimate the significance of rural public spending on productive investment of rural households across eastern, central and western regions of China. The results showed that only the characteristics of rural household affected the behavior of productive investments, but also the rural public investment such as transportation, telecommunication, electricity, infrastructures and rural areas hydraulic engineering construction made the difference.

Bidemi AT [29] examined the impact of development finance on agricultural growth in Nigeria from 2000-2010. The data gathered 
was presented in tables and analyzed using simple percentage method. Hypothesis was also tested using the chi-square method. Data analyzed indicated that there is a direct relationship between development finance and agriculture development and therefore it was recommended that farmers should be provided with adequate funds and that adequate extension services should be granted so as to improve farmer's capacity to produce more food. Uger FI [16] examined the impact of Federal Government's expenditure on the agricultural sector. The data used was sourced from the Central Bank of Nigeria Statistical Bulletin. Simple regression method was used to analyze the data which indicated impact of agricultural expenditure on its output from 1991 to 2010 . The R2 was 1 percent indicating a weak relationship between the variables are as a result of inadequate funding. It was recommended that government should reinforce its budgetary allocations to the agricultural sector, ensure proper release of funds, monitor agricultural inputs distribution to farmers and create commodity markets. Ishola SA [11] explored the average contribution of the agricultural sector to the national earning of Nigeria over the years, using a time series data from 1981 to 2010 sourced from the Central Bank of Nigeria Statistical Bulletin. The empirical perspective of the paper applied unit root test and co- integration, relying on the theoretical backing posited by Solow. It was found that a significant and positive relationship existed between government expenditure in the agricultural sector and the economic growth of Nigeria.

Summer A [30] examined the impact of health expenditures on agricultural labour productivity in order to inform the necessary policy decisions about targeting scarce public resources towards their most effective uses. The health sector expenditures in rural Tanzania was linked to health outcomes and agricultural labour productivity using data from the 2008 Household Budget Survey (10,975 households) and the 2007/08 Agricultural Census (52,594 households) across 113 districts in Tanzania. The results indicated that the marginal productivity of labour as well as land and fertilizers respond significantly and positively to health expenditures. These findings suggested that both the need and scope for targeting public expenditures in the health sector to achieve better agricultural growth outcomes cannot be over-emphasized. Adetiloye AK [31] examined the provision of credit to agricultural sector along with the performance of the Agricultural Guarantee Credit Scheme Funds (ACGSF)while at the same time evaluating the food security status of Nigeria. The study adopted the available data for the period 1978 to 2006because of data uniformity. It found out that though credit to the agricultural sector was significant it has not been growing relative to the economy. The ACGSF settled claims were negatively significant and the tardiness was observed in the claims process. The food security aspect showed that that Nigeria is food insecure as the import of food has been on the rise as the tests showed. Among the recommendations made to improve the current situation included further enlightenment campaigns to bring the youth into agriculture and the management of the ACGSF by the professionals.

Ammani AA [23] investigated the relationship between agricultural production and formal credit supply in Nigeria. The methodology employed in the study involved the development and estimation of three simple regression models relating agricultural output with formal credit while holding another explanatory variable constant. Findings of the paper indicated that formal credit was positively and significantly related to the productivity of the crop, livestock and fishing sectors of the Nigerian agriculture. Based on the findings it is recommended that government should continue to encourage the expansion of formal credit sources to reach as much farmers as possible. Lawal WA [32] examined the impact of informal agricultural financing on agricultural production in the rural economy of Kwara State, Nigeria. The source of data for this study was mainly primary which was collected using structured questionnaires from sampled farmers who were participating in three informal financing schemes namely: (i) periodic savings; (ii) money lending; and (iii) rotating savings in nine Local Government Areas spread through the three senatorial districts of Kwara State, Nigeria. Using a multi-stage random sampling method, a total of 1,350 farmers were selected for the study. The returned 1,249 copies of questionnaires were then processed using Ordinary Least Square method of regression analysis. The findings indicated that the institutions had a positive impact on agricultural production through only rotating savings being statistically significant at 10 percent level. Based on the results, the study recommended that the rotating loans should serve as an impetus to agricultural financing among the farmers in the rural areas with the improvement on the other informal financing sources with a view to increasing the membership drive of all the informal institutions.

Okurut N [33] affirmed that the informal financial sector played a key role in resource mobilization and allocation in developing economies. Bouman FJA [34] reported that in Cameroon, approximately $50 \%$ of the national savings and $27 \%$ of the total credit requirements was provided by the informal sector while Jones et al (1998), noted that 55\% of all private savings in Ghana were mobilized through informal sources. In India, it was reported by Timberg and Aiyar (1984), that informal credit markets accounted for approximately $20 \%$ of total commercial credit outstanding; while Bagachwa (1995) observed that approximately 55\% of startup capital for micro entrepreneurs in urban and rural areas in developing countries was provided by the informal financial sector. Okurut N [33] stated that informal credit was demanded for both productive investment (agriculture production or business) and consumption smoothing. Verhoef G [35] reported the great impact of "Stokvels", which is a type of Rotating and Savings Association (ROSCA) in South Africa, as informal market savings mobilizers. He stated that overtime "Stokvels" developed into a network of 
highly diversified savings and credit organization to suit the needs of all income groups. He went further to state that the "Stokvels" eventually emerged as a strong intermediary in the informal financial sector that the South African Reserve Bank (SARB) had to include them in the regulatory framework of the financial institutions in 1994. Flora MS [24] reported that the activities of the informal credit sector in the Philippines have been very prominent in the last three decades especially in the rice-growing areas where marketing agents' informal lending activities resulted in the rapid commercialization and intensified trading activity in the rural areas. This is a measure of the impact of informal financial institutions on the economic lives of the Philippines. Christensen G [36] reported that the impact of the informal financial institutions on informal sector activities differed from country to country depending on the level of the development of the financial markets. He stated that the informal financial sector increased in importance in proportion to the level of underdevelopment.

\section{Econometric Model}

Following the lead of Uger [16] and Iganiga and Unemehilin [3], the study used three econometric procedures to achieve its empirical results. The first econometric procedure examines the stationerity of the variable by applying Augmented Dickey-Fuller (ADF) method. The second procedure examined the existence of long-run relationship between government agricultural expenditures and agricultural output by applying the Johansen cointegration test, while the third application of the Vector Error Correction Model (VECM) which determined the short term dynamics to determine the direction of errors between dependent and independent variables. To capture agricultural expenditure and its impact on the agricultural output, the independent variables used was total government agricultural expenditure (TGEX), real exchange rate (REXCHR), economic openness (OPN), population growth (POPG), average annual rainfall (AAR) and agricultural output (AGO) which became the dependent variable. The data covered the period from 1990 to 2014 studied. The primary model used for the present study is specified as follows:

$$
\begin{gathered}
\underset{\mathrm{AGO}_{\mathrm{t}}=\beta_{0}}{\beta_{5} \text { REXCHR+et }}+\beta_{1} \mathrm{TGEX}+\beta_{2} \mathrm{BSCRA}+\beta_{3} \mathrm{AAR}+\beta_{4} \mathrm{POPGt}+ \\
\text { Eq (1) }
\end{gathered}
$$

$\beta_{0}=$ Constant

$\beta 1, \beta_{2}, \ldots \beta_{5}=$ Population parameters

AGO = Agricultural sector output

TGEX = Total government agricultural expenditure

BSCRA = Banking sector credit to agriculture

$\mathrm{AAR}=$ Annual average rainfall

POPG = Population growth
REXCHR $=$ Real exchange rate

$\mathrm{e}=$ Estimated error term

\section{Discussion of Results}

\section{Ordinary Least Squares Results}

From the results presented in Table 2 above, only average annual rainfall (AAR) and population growth (POPG) were found to be positive and very significant in explaining the changes in agricultural output in Nigeria; As a matter of fact, they lead agriculture productivity (Table 2). While total government agricultural expenditure (TGEX), banking sector credit to agriculture (BSCRA) and real exchange rate (REXCHR) were insignificant. BSCRA was rightly signed while both TGEX and REXCHR were wrongly signed. The adjusted R-squared of 0.994312 showed that the explanatory variables used in study accounted for approximately 99 per cent of the total variations in the dependent variable. The F-statistic had indicated that the overall regression was significant at 5 percent level. Judging from the coefficients of our explanatory variables, banking sector credit to agricultural sector (BSCRA), average annual rainfall (AAR), population growth (POPG) and real exchange rate (REXCHR) caused a positive change in agricultural productivity (AGO), while total government agricultural expenditure (TGEX) exerted a negative influence on agricultural productivity (AGO) in Nigeria.

Table 2: Showing results OLS Function.

\begin{tabular}{|c|c|c|c|c|}
\hline Variable & Coefficient & Std. Error & T-Statistic & Prob. \\
\hline TGEX & -0.576779 & 4.645464 & -0.124160 & 0.9030 \\
\hline BSCRA & 3.913172 & 4.098501 & 0.954781 & 0.3559 \\
\hline AAR & 2.174390 & 0.314737 & 6.908600 & $0.0000^{*}$ \\
\hline POPG & 66.33683 & 7.311063 & 9.073486 & $0.0000^{*}$ \\
\cline { 1 - 2 } REXCHR & 0.126867 & 2.015178 & 0.062956 & 0.9507 \\
\hline C & -2214.527 & 483.1405 & -4.583610 & $0.0004^{*}$ \\
\cline { 1 - 2 } R-squared & 0.994312 & & & \\
\cline { 1 - 2 } Adjusted R- \\
squared
\end{tabular}

Source: Computed by the Authors (2017) using E-views 9.0.

Key: *Significant at $1 \%$ level.

\section{Unit Root Test}

The first step involved in the data analysis was testing the order of integration of the individual variables under consideration. Researchers have developed several procedures for the test of order of integration. The most popular ones are Augmented Dickey-Fuller (ADF) test due to Dickey and Fuller (1979, 1981). 
Augmented Dickey-Fuller test relies on rejecting a null hypothesis of unit root test (that the variables are non-stationary) in favor of the alternative hypothesis of stationarity. The unit root results are therefore presented (Table 3).

Table 3: Showing results OLS Function.

\begin{tabular}{|c|c|c|c|}
\hline Variables & ADF @ Level & $\begin{array}{c}\text { ADF @ First } \\
\text { Difference }\end{array}$ & $\begin{array}{c}\text { Order of } \\
\text { Integration }\end{array}$ \\
\hline TGEX & -2.247600 & $-5.837474^{* * *}$ & $\mathrm{I}(1)$ \\
\hline AGO & -3.153983 & $-4.989585^{* * *}$ & $\mathrm{I}(1)$ \\
\hline BSCRA & -2.746473 & $-6.708948^{* * *}$ & $\mathrm{I}(1)$ \\
\hline AAR & -3.283464 & $-5.839348^{* * *}$ & $\mathrm{I}(1)$ \\
\hline POPG & -1.937456 & $-4.039485^{* * *}$ & $\mathrm{I}(1)$ \\
\hline REXCHR & -2.465483 & $-4.938474^{* * *}$ & $\mathrm{I}(1)$ \\
\hline
\end{tabular}

Source: Computed by the Authors (2017) using E-views 9.0.

Notes: All variables are expressed in natural logarithm.

*** implies first differenced

Interpretation of Result: The unit root test results showed that all the variables (government agricultural expenditure, agricultural output, bank credit to agricultural sector, average annual rainfall, population growth, and real exchange rate) were not stationary at levels but were significant at first difference. Hence, by taking their first difference they became stationary.

\section{Co-Integration Tests}

The second step is to test for the presence of co-integration between the variables of the same order of integration through forming a co-integration equation. The basic idea behind cointegration is that if, in the long-run, two or more variables move closely together, even though the variables themselves are trended, the difference between them would be constant. It is possible to regard these variables as defining a long-run equilibrium relationship, as the difference between them is stationary. This study used the Johansen co-integration test as presented (Table 4 \&5).

Table 4: Trace Test for Co-integration Result.

\begin{tabular}{|c|c|c|c|c|}
\hline Hypothesized & \multirow{2}{*}{ Eigenvalue } & Trace & $\mathbf{0 . 0 5}$ & Prob.** \\
\cline { 3 - 5 } No. of CE(s) & & Statistic & $\begin{array}{c}\text { Critical } \\
\text { Value }\end{array}$ & \\
\hline None* $^{*}$ & 0.953635 & 356.2204 & 95.75366 & 0.0001 \\
\hline At most $1^{*}$ & 0.973938 & 189.5034 & 69.81889 & 0.0006 \\
\hline At most $2^{*}$ & 0.768364 & 94.90331 & 47.85613 & 0.0003 \\
\hline At most $3^{*}$ & 0.604875 & 48.20564 & 29.79707 & 0.0002 \\
\hline At most $4^{*}$ & 0.439475 & 18.44756 & 15.49471 & 0.0349 \\
\hline At most $5^{*}$ & 0.087576 & 0.089475 & 3.841466 & 0.7799 \\
\hline
\end{tabular}

Trace test indicates 6 cointegration eqn(s) at the 0.5 level.

*denotes rejecting of the hypothesis at the 0.05 level.

**Mackinnon-Haug-Michelis (1999) p - values.
Interpretation of Result: From Table $4 \& 5$ above, both the Trace statistic and Max-Eigen statistic reported that there was presence of co-integration among these variables. This means that a long run interaction existed among these relevant variables. Both the Trace statistic and Max-Eigen statistic were greater than their respective critical values and significant at 5 percent level. As such, it was concluded that a long run equilibrium relationship rightly existed among these variables of interest used in our study.

Table 5: Trace Test for Co-integration Result.

\begin{tabular}{|c|c|c|c|c|}
\hline \multicolumn{4}{|c|}{ Unrestricted Cointegration Rank Test (Maximum Eigenvalue) } \\
\hline $\begin{array}{c}\text { Hypothesized } \\
\text { No. of CE(s) }\end{array}$ & Eigenvalue & $\begin{array}{c}\text { Max-Eigen } \\
\text { Statistic }\end{array}$ & $\begin{array}{c}\mathbf{0 . 0 5} \\
\text { Critical } \\
\text { Value }\end{array}$ & Prob.** $^{*}$ \\
\hline None* & 0.980382 & 156.7033 & 40.07757 & 0.0001 \\
\hline At most $1^{*}$ & 0.964754 & 97.51008 & 33.87687 & 0 \\
\hline At most $2^{*}$ & 0.786472 & 46.78217 & 27.58434 & 0.0001 \\
\hline At most $3^{*}$ & 0.646484 & 29.74284 & 21.13162 & 0.0024 \\
\hline At most $4^{*}$ & 0.524485 & 17.39442 & 14.2646 & 0.0155 \\
\hline At most 5 & 0.003757 & 0.07388 & 3.841466 & 0.7858 \\
\hline
\end{tabular}

Max - eigenvalue test indicates 6 cointegrating eqn(s) at the 0.15 level.

*denotes rejecting of the hypothesis at the 0.05 level.

**Mackinnon-Haug-Michelis (1999) p - values.

\section{Vector Error Correction Model (ECM)}

The error correction model (ECM) was presented (Table 6).

Table 6: Vector Error Correction Model (VECM) Results.

\begin{tabular}{|c|c|c|c|c|}
\hline Variables & Coefficient & Std. Error & t-Statistic & Prob. \\
\hline ECM (-1) & -0.57243 & 0.28267 & -2.02509 & $0.0210^{* *}$ \\
\hline D (TGEX (-1)) & 1.348317 & 0.47884 & 2.81581 & $0.0134^{* *}$ \\
\hline D (TGEX (-2)) & 1.328176 & 0.4769 & 2.785 & $0.0291^{* *}$ \\
\hline D (AAR (-1)) & 0.454287 & 0.14097 & 3.22248 & $0.0189^{* *}$ \\
\hline D (AAR (-2)) & 0.062481 & 0.23258 & 0.26863 & 0.1932 \\
\hline D (BSCRA (-1)) & -0.3346 & 0.73193 & -0.45714 & 0.1795 \\
\hline D (BSCRA (-2)) & 0.326037 & 0.3446 & 0.94612 & 0.2907 \\
\hline D (POPG (-1)) & -0.67762 & 0.12291 & -5.51307 & $0.0043^{* * *}$ \\
\hline D (POPG (-2)) & -0.15638 & 0.03118 & -5.01421 & $0.0013^{* * *}$ \\
\hline D (REXCHR (-1)) & -0.21074 & 0.6248 & -0.33728 & 0.7262 \\
\hline D (REXCHR (-2)) & 0.374787 & 0.53002 & 0.70711 & 0.4911 \\
\hline C & -28.7682 & 13.0646 & -2.20199 & $0.0306^{* *}$ \\
\hline Adj. R-Squared & 0.613454 & & & \\
\hline F-statistic & 5.849474 & & & \\
\hline Prob(F-statistic) & 0.035638 & & & \\
\hline Durbin Watson & 2.014874 & & & \\
\hline
\end{tabular}

Source: Author's E-views Computations (2017)

Key: ***and **denote $1 \%$ and $5 \%$ levels of significance, respectively 
Interpretation of Results: Table 6 above shows the vector error correction model results. From the table, it was discovered that the coefficient of determination (Adj. R-squared) is 0.613454 . Therefore, 61 percent variation in agricultural production output (AGO) was explained by total government expenditure (TGEX), banking sector credit to agriculture (BSCRA), average annual rainfall (AAR), population growth (POPG) and real exchange rate (REXCHR). The coefficient of the ECM appeared with the negative sign and it was statistically significant at 1 percent level. It then meant that, the short run problems have been adjusted to longrun equilibrium. The ECM results also show that agricultural output adjusted rapidly to changes in the dependent variables by57 percent. Also, the Durbin Watson value of 2.014874 which is approximately 2.0, suggested a lesser level of autocorrelation is expected. The F-statistic of 5.849474 is significant at the 5 percent level, meaning that the overall model, all in all, is satisfactory.

Going through these results, the lag one and two forms of the explanatory variable (TGEX), were positively signed and statistically significant. It also shows that total government agricultural expenditure (TGEX) had a positive and significant effect on agricultural output (AGO) in Nigeria during the period studied. The implication of this result is that a unit change in government expenditure caused agricultural output to accelerate. This, findings are in tandem with a priori expectations. With these results, the alternative hypothesis which stated that there is a significant relationship between aggregate government expenditures and agricultural output in Nigeria was accepted.

Similarly, the coefficient of annual average rainfall (AAR) for the lag one was positively signed and statistically significant at 5 percent level, while the lag two period was positive and insignificant. This means that average annual rainfall had impacted on agricultural output in Nigeria positively and significantly every year. Furthermore, the coefficient of population growth rate (POPG) is outstanding negative and most significant at both lag one and two. In fact, it led agricultural output in Nigeria. The result that changes in population caused agricultural output to depress in Nigeria. This is attributed to the fact that increasing population could result to increase in labour force in a situation hereby we depend less on mechanical agriculture as at the moment. With this result, it was accepted that population growth has a significant effect on agricultural output in the Nigerian economy. It speaks volume in the need to the government to inject more funding to agriculture in the area of the country being provided to go into mechanized improved agricultural practice in the years ahead. Finally, the coefficient of real exchange rate (INF) at lag one and lag two were not statistically significant at 5 percent in influencing the changes in agricultural output. Therefore, real exchange rate was considered to be an insignificant variable in this regard. However, its negative effect on agricultural productivity clearly shows that a high exchange rate portends a bad omen for importation of raw materials that go into agriculture produce.

\section{Conclusion and Recommendations}

The economic history of Nigeria is agro-based. Agricultural production provides employment opportunities and a source of income to about 80 percent of the country's population. It is also a source of food security, raw materials to local industries and generates foreign exchange earnings for the country. The findings of this paper revealed that there exists positive and significant relationship between government agricultural expenditure (financing) and its output, although a weak one, as rightly shown in our regression analysis. As a sector that provides basic foundation to the Nigerian economy, increased improvement in agricultural production would not only enable Nigeria to feed its teeming population but it would also assure a return to its former position (glory) as an exporter of agricultural products to global markets in the years ahead.

Based on the findings of this study we recommended the following for immediate policy actions in the times thus:

a) That since the coefficient of annual rainfall positively and significantly influenced agricultural yields in Nigeria government should ensure that meteorically agencies which forecast annual rainfalls be well funded and catered for and that their recommendations be followed to the letter so as to be getting good farm produce annually and thereby in minimize agricultural losses due to vagaries of weather in our agricultural investment climate [37].

b) That because of the shortfall in agricultural outputs as a result of poor financing (funding) by various governments (Federal, States and Locals) as revealed in the study, governments should be more proactive in insisting on the private sector, especially, the financial sector to set aside funds annually for agricultural financing and rescue to compliment government efforts as we are presently doing in education sector via TetFund. Moreover, agricultural term loans should always be extended to farmers for long-term funding consideration for large scale farming due to risks inherent in agricultural lending [38].

c) Above all, the Federal Government needs to take a holistic appraisal of agricultural programmes and schemes, with a view of streamlining them to meet the dynamics of the times, for the benefits of the Nigerian citizenry [39-44]. Nigeria should, as a matter of urgency, go into mechanized farming to boost her agric produce in rice and palm oil, maize, cassava, etc as we used to lead the world in the 1960s [45,46].

\section{References}

1. Alabi RA (2014) Impact of Agricultural Foreign Aid on Agricultural Growth in Sub-Saharan Africa: A Dynamic Specification. AGRODEP Working Paper 0006.

2. Akintunde WA, Adesope AA, Okruwa VO (2013) An Analysis of Federal Government Expenditure and Monetary Policy on Agricultural Output in Nigeria. International Journal of Economics, Finance and Management 
Sciences 1(6): 310-317.

3. Iganiga BO, Unemhilin DO (2011) The Impact of Federal Government Agricultural Expenditure on Agricultural Output in Nigeria. J Economics 2(2): 81-88.

4. Okumadewa F (1997) Poverty and Income in Nigeria: Measurement and Strategies for Reform. A Paper Presented at the Vision 2010 Workshop, Abuja.

5. FAO (2006) The State of Food Security in the World. FAO, Rome, USA.

6. Lopez R (2004) Effect of the Structure of Rural Public Expenditures on Agricultural Growth and Rural Poverty in Latin America. Rural Development Unit Sustainable Development Department InterAmerican Development Bank 1300 New York Avenue, NW Washington, DC, USA.

7. Yeun YS (2013) Impact of Public Expenditures on Agricultural Production Investment of Chinese Rural Households. A BSc Degree Project Submitted to Hong Kong Baptist University.

8. Heisey P, Wang SL, Fugile K (2011) Public Agricultural Research Spending and Future U.S. Agricultural Productivity Growth: Scenarios for pp. 2010-2050.

9. Knox L (2011) What is the Impact of Infrastructural Investments in Roads, Electricity and Irrigation on Agricultural Productivity? Department for International Development.

10. Curtis M (2013) Improving African Agriculture Spending: Budget Analysis of Burundi, Ghana, Zambia, Kenya and Sierra Leone.

11. Ishola SA, Olaleye SO, Ajayi EO, Femi E (2013) Government Expenditure on Agricultural Sector and Economic Growth in Nigeria (1981 - 2010). IOSR Journal of Humanities and Social Science (IOSR-JHSS). 8(4): 62-67.

12. Mogues T, Bingxin Y, Fan S, McBride L (2012) Agricultural Development Economics Division Food and Agriculture Organization of the United Nations. ESA Working paper No. pp. 12-17.

13. Ramaila M, Mahlangu S, Toit D (2011) Agricultural Productivity in South Africa: Literature Review. Department of Agriculture, Fisheries and Forestry, Republic of South Africa.

14. Ewubare DB, Eyitope JA (2015) The Effects of Public Expenditure on Agricultural Production Output in Nigeria. Journal of Research in Humanities and Social Science 3(11): 7-23.

15. Ukeje RO (2003) Macroeconomics: An Introduction. Port-Harcourt Davidson Publication.

16. Uger FI (2013) The Impact of Federal Government's Expenditure on the Agricultural Sector in Nigeria. Publication of Nasarawa State University, Keffi.

17. Ebere C, Osundina K (2012) Government Expenditure on Agriculture and Economic Growth in Nigeria. International Journal of Science and Research (IJSR). ISSN (Online) pp. 2319-7064.

18. Akroyd S, Smith L (2007) Review of Public Spending to Agriculture. A joint DFID/World Bank study.

19. Llanto GM (2012) The Impact of Infrastructure on Agricultural Productivity. Discussion Paper Series No pp. 2012-12.

20. Aku PS (1995) Comparative Analysis of NACB and ACGS Loan Disbursement to Agriculture in Nigeria. Journal of Social and Management Studies 2: 99-108.

21. World Bank (1986) Trade and Pricing Policies in World Agriculture. World Development Report 1986. Oxford University Press, New York, USA.

22. Uremadu SO, Onyele KO, Ariwa FO (2016) The Impact of Selected Agricultural Exports on Growth of the Domestic Economy. Prime Journal of Administration and Management 6(3): 2035-2046.
23. Ammani AA (2012) An Investigation into the Relationship between Agricultural Production and Formal Credit Supply in Nigeria. International Journal of Agriculture and Forestry 2(1): 46-52.

24. Flora MS, Ray D (1997) Vertical Links between Formal and Informal Financial Institutions. Review of Development Economics 1(1): 34-56.

25. Oboh VU (2008) Farmers' Allocative Behavior in Credit Utilization: A Case Study of Arable Crop Farmers in Benue State, Nigeria. PhD dissertation, Agricultural Economics and Extension Programmed, Abubakar Tafawa Balewa University, Bauchi, Nigeria.

26. Ruma SA (2008) Nigeria Ranks $20^{\text {th }}$ on Global Hunger Index - Minister for Agriculture. The Online Punch Newspaper.

27. Saungweme T, Matandare M (2014) Agricultural Expenditure and Economic Performance in Zimbabwe (1980-2005). International Journal of Economics Research 5(5): 50-59.

28. Odi N (2013) Agricultural Financing in Nigeria: An Empirical Studyof Nigerian Agricultural Co-operative and Rural Development Bank (NACRDB): 1990-2010. Journal of Management Research 5(2).

29. Bidemi AT (2013) The Impact of Development Finance on Agricultural Growth in Nigeria (A Case Study of Bank of Agriculture). Being a Research Project Submitted to the Department of Banking and Finance, Faculty of Management Sciences, University of Abuja in Partial Fulfillment of the Requirement for the Award of Bachelor of Sciences Degree in Banking and Finance.

30. Summer A, Ousmane B, Ligane S, John U (2013) GovernmentExpenditures, Health Outcomes and Marginal Productivity of Agricultural Inputs: The Case of Tanzania. Journal of Agricultural Economics 65(3): 637-661.

31. Adetiloye AK (2012) Agricultural Financing in Nigeria: An Assessment of the Agricultural Credit Guarantee Scheme Fund (ACGSF) For Food Security in Nigeria (1978-2006). J Economics 3(1): 39-48.

32. Lawal WA, Abudlahi IB (2011) Impact of Informal Agricultural Financing on Agricultural Production in the Rural Economy of Kwara State, Nigeria. International Journal of Business and Social Science. 12(19).

33. Okurut N, Thuto B (2007) Informal Financial Markets in Botswana: A Case Study of Gaborone City. Study prepared for Botswana Institute for Development Policy Analysis (BIDPA) 26(2): 255-270.

34. Bouman FJA (1995) Rotating and Accumulating Savings and Credit Associations: A Development Perspective. World Development 23(3): 371-384.

35. Verhoef G (2001) Informal Financial Service Institutions for Survival: African Women and Stokvels in Urban South Africa, 1930-1998. Enterprise and Society 2(2): 259-296.

36. Christensen G (1993) The Limits of Informal Financial Intermediation. World Development 21(5): 721-731.

37. Uremadu SO, Sunday DU (2016) Investment Climate and the Profitability of the Nigerian Commercial Banks (1990 - 2013): A Return on Asset Approach). Prime Journal of Business Administration and Management (BAM) 6(3): 2047-2055.

38. Uremadu SO (2000) Bank Management: Basic Issues in Money, Bank Lending \& Credit Administration. Benin City Mindex Publishing Company.

39. Akintola A (2011) Nigeria: A New Perspective. Being a paper presented by the Minister of Agriculture on the Neglect of Agricultural Sector $18^{\text {th }}$ September, Kano.

40. Alpuerto V, Diao X, Slan S, Nwafor M (2009) Agricultural Investment for Growth and Poverty Reduction in Nigeria. International Food Policy Research, Abuja p.4.

41. Bagachwa MSD (1995) Financial Integration and Development in SubSaharan Africa: A Study of Informal Finance in Tanzania. Overseas Development Institute Working Paper 79: 50. 
42. Gujaratu DN, Porter DC (2009) Basic Econometrics. McGraw Hill Co New Delhi.

43. Okoh RN (2004) Global Integration and the Growth of Nigeria's Nonoil Exports. Paper Presented at the African Conference $21^{\text {st }}-22^{\text {nd }}$, March 2004, Oxford, UK

44. Oriola EO (2009) A Framework for Food Security and Poverty Reduction in Nigeria. European Journal of Social Science 8(1): 132-139.
45. People's Daily (2011) Report on Agriculture in Nigeria. Lagos: Peoples Media Publication pp.18.

46. Sanusi SL (2010) Growth Prospects for the Nigerian Economy. Convocation Lecture Delivered at the Igbinedion University Eighth Convocation Ceremony, Okada, Edo State.

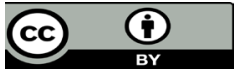

This work is licensed under Creative Commons Attribution 4.0 License

To Submit Your Article Click Here:

Submit Article

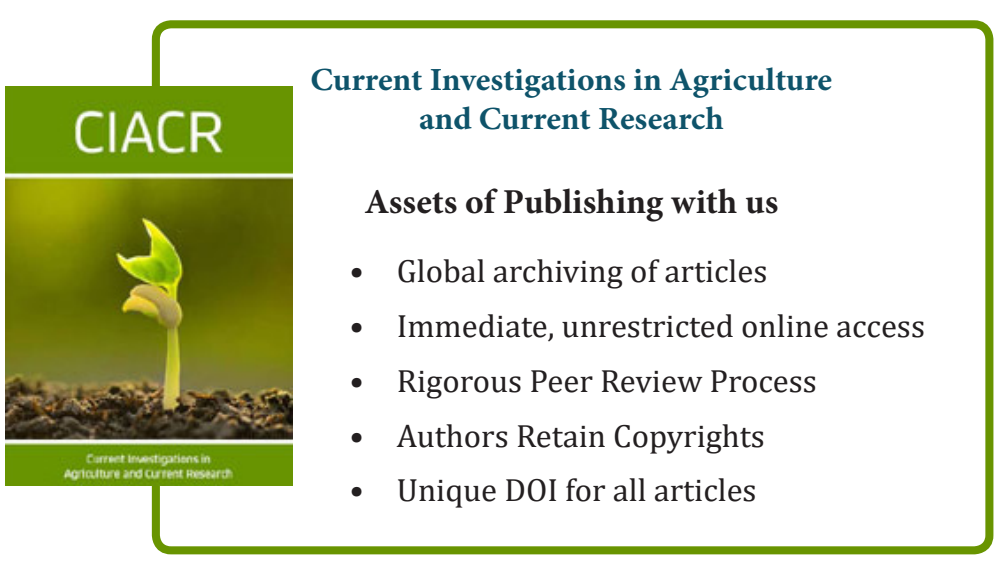

